\title{
Investigation of the Effects of Marital Adjustment on Sexual Life Quality of Married Women
}

\author{
Sevinç Köse Tuncer ${ }^{1, *}$, Emine Aydin², Necla Kasimoğlư ${ }^{1}$, Burcu Ağdemir ${ }^{1}$, Sebahat Atalikoğlu Başkan ${ }^{1}$ \\ ${ }^{1}$ Erzincan Binali Yıldırım University Faculty of Health Sciences \\ Erzincan,Turkey \\ ${ }^{2}$ Trakya University Keşan School of Health \\ Edirne, Turkey \\ *Corresponding author's email: svnc1024 [AT] hotmail.com
}

\begin{abstract}
---
Objective: The aim of this study is to determine the effect of marital adjustment on the quality of sex life in married women.

Method: As a descriptive study, the universe of the present study consists of married women consulting to an education and research hospital and primary care clinics in a province while the sample is composed of 365 voluntary married women that are open to dialogue. In collecting the data, "Information form" containing socio-demographic background, "Marriage Adjustment form (MAF) and sexual life quality scale for woman (SFQSW) were used. In analysing the data, arithmetic mean, percentage, frequency, Mann Whitney-U test, Kruskall Wallis Analysis and Spearman Correlation Analysis were employed.
\end{abstract}

Findings: Arithmetic score of the MAF is $43.58 \pm 9.83$ and that of SFQSW is $79.88 \pm 19.57$ while significant relation between the scores was found in positive direction $(p<0.05)$.

Results: The more marital adjustment increases in women, the better the sexual life quality is. In order to increase the level of well-being and life quality in marriage, nurses are suggested to counsel the couples and family consultants are advised to inform the families on sexual issues and improve their communication skills.

Keywords--- Sexual Life Quality, Marital Adjustment, Women

\section{INTRODUCTION}

Marriage is a legally accepted or community-approved relationship between two or more people, giving a variety of rights and responsibilities to the parties and often involving sexuality[1,2]. Marital adjustment is defined as the marriage of couples who interact with each other, can agree on matters concerning marriage and family and can solve their problems in a positive way. Therefore, the capacity of each spouse to maintain a relationship is important in marital adjustment [3]. Marriage experience involves satisfaction stemming from positive partner relations, sharing roles that will enable sexual maturation, accepting social roles and responsibilities, supporting personal entrepreneurship and creativity[4].

There are many factors ensuring the continuity, happiness and harmony of the family. The facts that the spouses make selfsacrifice of their habits, value judgements and personal freedoms when needed, respect the personal values and characteristics of their new life partners and there is the understanding of "we" instead of "I" in the family are among the main factors that ensure marital adjustment. In addition, mutual love, respect, self-sacrifice, empathizing, meeting basic needs, struggling with difficulties and learning to share positively affect family continuity[5]. Sexuality, which is one of the basic requirements of spouses, has an important place in ensuring marital adjustment. While sexuality is expressed as a symbol of blessing, purity, abundance and fertility in the society in the context of marriage, it is marked off with rules, myths, taboos and prohibitions[4]. Sexuality is a concept with biological, psychological, socio-cultural, traditional, moral, religious, anthropological, political and economic dimensions. Sexual functions are a process involving all body, mainly the central nervous system, and a complex interaction of more than thirty hormones and chemicals. In order to maintain a healthy and happy sex life, it is important to have a physically and spiritually healthy body and to determine how, with whom, when, where and how to get sexual satisfaction. Sexual health deterioration is one of the health problems that make 
couples unhappy because it adversely affects the physical and mental health of spouses. In addition, it deteriorates family health and social health [5].

Studies on the subject are insufficient and in recent years, data on interaction between adjustment in marriage and sexuality have begun to be emphasized [4]. Studies have shown that there is a relationship between marital adjustment and sexual life. In the studies, it has been determined that marital adjustment, feelings towards spouse and happiness in marriage affect sexuality and it has been concluded that in compatible, happy marriages without conflicts, there is more sexual satisfaction $[6,7,8,9,10,11]$.

Sexuality plays an important role in all stages of marriage, which is one of the basic elements of society. The problems occurring in other areas of marriage may have effects on sexuality, and problems in sexual life may be reflected in the marriage relationship. Both marriage and sexual functions can be affected in different degrees and ways by biological, psychological and even sociocultural factors[4]. It seems difficult to effectively address marriage issues, find solutions and to preserve family integrity as long as the various factors that affect marital adjustment are not understood. The nursing profession has a consultative role. In line with this role, mentoring married couples about marriage and sexuality will contribute to protect family integrity. The fact that the number of the studies on the reflection of marriage on sexuality and sexuality on marriage is limited in our country presents this issue as a research area that needs to be emphasized. Therefore, the aim of this study is to investigate the effect of marital adjustment on quality of sexual life in married women.

\section{MATERIAL AND METHOD}

\section{Type of Research}

The research was planned as descriptive study in order to determine the effect of marital adjustment on the quality of sexual life in married women.

\section{Place and Time of Research}

The study was conducted on married women who applied to an education and research hospital and family health centers of a city.

\section{Research Population and Sample}

The population of this study consisted of married women who applied to a education and research hospital and family health centers of a city. Sampling selection was not made in the research and the study included 365 married women who were open to communication and volunteered to participate in the study between specified dates.

\section{Data Collection}

In the collection of data; "The Information Form" developed by researchers using literature [12,13] "Marital Adjustment Questionnaire" to determine the adjustment of married women to marriage and "Sexual Quality of Life Questionnaire" to determine the quality of sexual life of married women were used. The information form and the scales were filled by the researchers after interviewing married women one-to-one and necessary explanation was made to women. Participation in the study was voluntary and it was said to women that they could leave the study at any time and they would adhere to the principle of confidentiality.

\section{The Information Form:}

This form includes a total of 28 questions which can determine the socio-demographic status (age, education, occupation, spouse education, income, family type, number of children alive, age of first marriage, number of years of marriage, form of marriage with spouse, solution of problems between spouses etc.) of women.

\section{Marital Adjustment Questionnaire (MAQ):}

The questionnaire consisting of 15 articles was developed by Locke and Wallace (1959) and validity and reliability study in Turkey was conducted by Kışlak-Tutarel (1999) [13]. The scores that can be taken from the questionnaire vary between 1 and 60 points. While high score indicates adjustment in marriage, low score indicates maladjustment. The questionnaire measures both the status of agreement or disagreement on issues such as family budget, expression of emotions, friends, sexuality and philosophy of life along with general marital adjustment and relationship style in the practices of trust, conflict resolution and leisure and non-home activities.

Each question is given a score between 0 and 6 in the scoring of the scale. Accordingly, the evaluation method is like this: $1^{\text {st }}$ item is 0-6 points; the items between 2-9 are 0-5 points; the items between 10-14 are 0-2 points; the items between 11 13 are $0-3$ points; $12^{\text {th }}$ item is 0 point if while one of the spouses chooses to sit at home and the other chooses to do something outside, it is 1 point if both spouses choose to do something outside and it is 2 points if both spouses choose to 
sit at home; and $15^{\text {th }}$ item is $0-2$ points. In the reliability study of the scale; the internal consistency coefficient was calculated as .84, and the half-test test reliability was .84. The correlation coefficient was calculated as 57 in the reliability study performed by the test-retest method (K1şlak-Tutarel, 1999, 54-55). In our study, the correlation coefficient was found to be 0.887 .

Sexual Quality of Life Questionnaire-Female :

Turkish validity and reliability study for women in the age group 18-65 of the questionnaire developed for use in measuring the sexual quality of life by Symonds, Boolell and Quirk (2005) was done by Tuğut and Gölbaş1 (2010).

The questionnaire consists of 18 items in the six likert type that individuals can respond themselves and that are easy to implement. Each item is expected to be answered by considering the sexual life in the last four weeks. It is stated that in the original questionnaire each item can be scored between 1-6 or 0-5. 1-6 point system $(1=$ Totally agree, $2=$ Strongly agree, 3 = Partly agree, 4 = Partially disagree, $5=$ Strongly disagree, $6=$ Never agree)was used in this study. The range of points that can be taken from the questionnaire is between 18-108. On the other hand, in the $0-5$ scoring system, the score range is 0-90. Before the total score is calculated, The scores of items 1, 5, 9, 13, 18 must be reversed. The total score from the questionnaire, regardless of which scoring system is used, is converted to 100 . To convert the total questionnaire score to 100 , it is stated to use (Raw score taken from questionnaire-18) x100 / 90 formula. For example, for an individual with a total of 63 raw points from the questionnaire, questionnaire score converted to 100 is $(63-18) \times 100 / 90=50$. The higher the score obtained from the questionnaire, the better the sexual quality of life. As a result of the Cronbach $\alpha$ reliability analysis, the reliability coefficient of the questionnaire was found to be 0.83 [14]. Cronbach $\alpha$ coefficient was found as 0.931 in our study.

\section{Statistical Analysis of Data}

Data were analyzed with SPSS for Windows 17 package program. In the analysis of the data, numbers, percentages, minimum and maximum values, mean and standard deviations as well as statistical analyzes in the following table were used.

Table 1. Statistical Tests Used in Data Analysis

\begin{tabular}{llc}
\hline Variance & \multicolumn{1}{c}{$\begin{array}{c}\text { For normally distributed } \\
\text { measurements }\end{array}$} & $\begin{array}{c}\text { For measurements } \\
\text { not normally } \\
\text { distributed }\end{array}$ \\
\hline $\begin{array}{l}\text { Family structure, working status, social security, } \\
\text { family type, number of marriages, working status } \\
\text { of spouse, kinship with spouse, family structure of } \\
\text { spouse }\end{array}$ & t test in independent groups & Mann Whitney-U test \\
\hline $\begin{array}{l}\text { Level of education, place of residence, the place } \\
\text { where individual lived the longest, income level, } \\
\text { mode of delivery, method of family planning, } \\
\text { marriage year, form of marriage, marriage } \\
\text { experience, the way the problems are solved, } \\
\text { physical violence, emotional violence, tension } \\
\text { experience, mood, education level of spouse, the } \\
\text { place where spouse lived the longest }\end{array}$ & $\begin{array}{l}\text { Analysis of Variance (As a } \\
\text { further analysis, in cases } \\
\text { where the variance was } \\
\text { distributed homogeneously } \\
\text { ofD and Tukey were used; in } \\
\text { used.) }\end{array}$ & Kruskall Wallis \\
$\begin{array}{l}\text { Age, number of children, age of marriage and age } \\
\text { of spouse }\end{array}$ & Pearson Correlation Analysis \\
\hline $\begin{array}{l}\text { The relationship between SQLQ-F and MAQ } \\
\text { Internal consistency }\end{array}$ & Pearson Correlation Analysis & $\begin{array}{c}\text { Spearman Correlation } \\
\text { Analysis }\end{array}$ \\
\hline Normality distribution of data & Cronbach $\alpha$ coefficient & Analysis \\
\hline
\end{tabular}

\section{Ethical Approach}

The ethics committee approval was obtained before the study was started and necessary permits were obtained from the relevant institutions. Individuals participating in the research were informed about the aim of the study and they were explained that they were free to participate in or not participate in the research and that any shared information will remain hidden. Those who agreed to participate in the study voluntarily were included in the study. In the study, "Benefit first" principle that includes the rule of "not being damaging, but being beneficial" was taken into consideration.

\section{FINDINGS}


As seen in Table 2, 34\% of women are university graduates, $75.4 \%$ of them reside in the city center, $48.8 \%$ of them lived in the city center for the longest period and $58.1 \%$ of them live in a nuclear family. $51.8 \%$ of women do not work, $93.7 \%$ have social security, $84.1 \%$ live in a nuclear family and $53.2 \%$ have income that is equal to their expenses. The average of age of women is $32.33 \pm 7.59$; number of children is $1.79 \pm 1.34$; age of marriage is $22.65 \pm 3.73$ and spouse age is $35.91 \pm 8.29$. $40.0 \%$ of the spouses of women are university graduates, $93.4 \%$ are employed, $83.8 \%$ are not relatives, $51.2 \%$ live in the city center and $53.2 \%$ live in a nuclear family.

Tabe 2. Demographic Characteristics of Married Women $(\mathbf{n}=\mathbf{3 6 5})$

\begin{tabular}{|c|c|c|c|}
\hline & & $\mathbf{n}$ & $\%$ \\
\hline \multirow{5}{*}{ Education Level } & Illiterate & 11 & 3.0 \\
\hline & Literate & 14 & 3.8 \\
\hline & Primary School & 120 & 32.9 \\
\hline & High School & 96 & 26.3 \\
\hline & University & 124 & 34.0 \\
\hline \multirow{3}{*}{ Place of Residence } & Province & 275 & 75.4 \\
\hline & District & 53 & 14.5 \\
\hline & Village-Hamlet & 37 & 10.1 \\
\hline \multirow{3}{*}{$\begin{array}{l}\text { The Place Where Individual Lived } \\
\text { the Longest }\end{array}$} & Province & 178 & 48.8 \\
\hline & District & 91 & 24.9 \\
\hline & Village-Hamlet & 96 & 26.3 \\
\hline \multirow{2}{*}{ Family Strucure } & Nuclear Family & 212 & 58.1 \\
\hline & Extended Family & 153 & 41.9 \\
\hline \multirow{2}{*}{ Working Status } & Yes & 176 & 48.2 \\
\hline & No & 189 & 51.8 \\
\hline \multirow{2}{*}{ Social Security } & Yes & 342 & 93.7 \\
\hline & No & 23 & 6.3 \\
\hline \multirow{4}{*}{ Family Type } & Nuclear Family & 307 & 84.1 \\
\hline & Extended Family & 58 & 15.9 \\
\hline & Income is less than expenses & 87 & 23.8 \\
\hline & $\begin{array}{l}\text { Income is equal to expenses } \\
\text { Income is more than expenses }\end{array}$ & 194 & 53.2 \\
\hline
\end{tabular}

Income Level

\begin{tabular}{|c|c|c|c|c|c|}
\hline & \multicolumn{3}{|c|}{ Illiterate } & 3 & .8 \\
\hline & \multicolumn{3}{|c|}{ Literate } & 10 & 2.8 \\
\hline Education Level of Spouse & \multicolumn{3}{|c|}{ Primary School } & 92 & 25.2 \\
\hline & \multicolumn{3}{|c|}{ High School } & 114 & 31.2 \\
\hline & \multicolumn{3}{|c|}{ University } & 146 & 40.0 \\
\hline & \multicolumn{3}{|c|}{ Employed } & 341 & 93.4 \\
\hline Working Status of Spouse & \multicolumn{3}{|c|}{ Unemployed } & 24 & 6.6 \\
\hline & \multicolumn{3}{|c|}{ Yes } & 59 & 16.2 \\
\hline Kinship with Spouse & \multicolumn{3}{|l|}{ No } & 306 & 83.8 \\
\hline & \multicolumn{3}{|c|}{ First } & 351 & 96.2 \\
\hline Number of Marriage of Spouse & \multicolumn{3}{|c|}{2} & 14 & 3.8 \\
\hline & \multicolumn{3}{|c|}{ Province } & 187 & 51.2 \\
\hline The Place Where Spouse Lived the & \multicolumn{3}{|c|}{ District } & 74 & 20.3 \\
\hline & \multicolumn{3}{|c|}{ Village-Hamlet } & 104 & 28.5 \\
\hline \multirow{3}{*}{ Family Structure of Spouse } & \multicolumn{3}{|c|}{ Nuclear Family } & 194 & 53.2 \\
\hline & \multicolumn{3}{|c|}{ Extended Family } & 171 & 46.8 \\
\hline & $\mathbf{n}$ & Min. & Max. & Mean & SD. \\
\hline$\overline{\text { Age }}$ & 365 & 18 & 60 & 32.33 & 7.59 \\
\hline The Number of Children & 365 & 0 & 8 & 1.79 & 1.34 \\
\hline Age of Marriage & 365 & 13 & 39 & 21.65 & 3.73 \\
\hline Age of Spouse & 365 & 15 & 66 & 35.91 & 8.29 \\
\hline
\end{tabular}

Table 3. Marriage and Fertility Characteristics of Married Women 


\begin{tabular}{|c|c|c|c|}
\hline \multirow{5}{*}{ The way problems are solved } & Talking and discussing & 263 & 72.1 \\
\hline & Remaining silent & 75 & 20.5 \\
\hline & Leaving home & 8 & 2.2 \\
\hline & Fighting-violence & 9 & 2.5 \\
\hline & $\begin{array}{l}\text { Reflection on families and the } \\
\text { acquaintances }\end{array}$ & 10 & 2.7 \\
\hline \multirow{3}{*}{ Physical Violence } & Often & 4 & 1.1 \\
\hline & Sometimes & 31 & 8.5 \\
\hline & Never & 330 & 90.4 \\
\hline \multirow{3}{*}{ Emotional Violence } & Often & 20 & 5.5 \\
\hline & Sometimes & 134 & 36.7 \\
\hline & Never & 211 & 57.8 \\
\hline \multirow{3}{*}{ Tension Experience } & Often & 35 & 9.6 \\
\hline & Sometimes & 287 & 78.6 \\
\hline & Never & 43 & 11.8 \\
\hline \multirow{4}{*}{ Mood } & Love-respect & 310 & 84.9 \\
\hline & Hate-Tension & 10 & 2.7 \\
\hline & Monotony-ordinariness & 38 & 10.4 \\
\hline & Fear-timidity & 7 & 2 \\
\hline \multirow{4}{*}{ Type of Delivery } & No delivery & 64 & 17.5 \\
\hline & Normal delivery & 178 & 48.8 \\
\hline & Abdominal delivery & 94 & 25.8 \\
\hline & Normal and abdominal delivery (both) & 29 & 7.9 \\
\hline \multirow{7}{*}{ Family Planning Method } & No method & 86 & 23.6 \\
\hline & Condom & 104 & 28.5 \\
\hline & Ria & 57 & 15.6 \\
\hline & Retraction & 50 & 13.7 \\
\hline & Tubal ligation & 13 & 3.6 \\
\hline & Pill & 46 & 12.5 \\
\hline & Injection & 9 & 2.5 \\
\hline \multirow{3}{*}{ Marriage Year } & Between 1-10 years & 220 & 60.3 \\
\hline & Between 11-20 years & 87 & 23.8 \\
\hline & 21 years and above & 58 & 15.9 \\
\hline \multirow{3}{*}{ Number of Marriage } & First & 352 & 96.4 \\
\hline & 2 & 9 & 2.5 \\
\hline & 3 and above & 4 & 1.1 \\
\hline \multirow{2}{*}{ Form of Marriage } & Love and flirt marriage & 194 & 53.2 \\
\hline & Arranged marriage & 171 & 46.8 \\
\hline \multirow{5}{*}{ Marriage Experience } & Very good & 122 & 33.4 \\
\hline & Good & 165 & 45.2 \\
\hline & Average & 68 & 18.6 \\
\hline & $\mathrm{Bad}$ & 5 & 1.4 \\
\hline & Very bad & 5 & 1.4 \\
\hline
\end{tabular}

$48.8 \%$ of women had normal delivery, $76.4 \%$ had family planning, $60.3 \%$ were married between 1 and 10 years and $96.4 \%$ had their first marriage. $53.2 \%$ of women had love or flirt marriage, $45.2 \%$ considered marriage experience as good, $72.1 \%$ talked and discussed their problems and $90.4 \%$ never experienced physical violence. $57.8 \%$ of women never experienced emotional violence, $78.6 \%$ sometimes experienced tension, and $84.9 \%$ answered love-respect to their mood (Table 3).

Table 4. Marital Adjustment and Sexual Quality of Life Questionnaires of Married Women - Distribution of the Points Received From the Female Form $(n=365)$

\begin{tabular}{lccccc}
\hline & n & Min. & Max. & Mean. & SD. \\
\hline MAQ & 365 & 9 & 60 & 43.58 & 9.83 \\
Sexual Quality of Life Questionnaire-Female Form & 365 & 11.11 & 100 & 79.88 & 19.57 \\
\hline
\end{tabular}

As shown in Table 4, the average score of the MAQ was $43.58 \pm 9.83$ and the average score of Sexual Quality of Life Questionnaire - Female Form was $79.88 \pm 19.57$. 
Table 5. Marital Adjustment and Sexual Quality of Life Questionnaires According to Demographic Characteristics and Spouse Characteristics of Married Women - Comparison of the Scores Obtained from the Female $\operatorname{Form}(\mathbf{n}=365)$

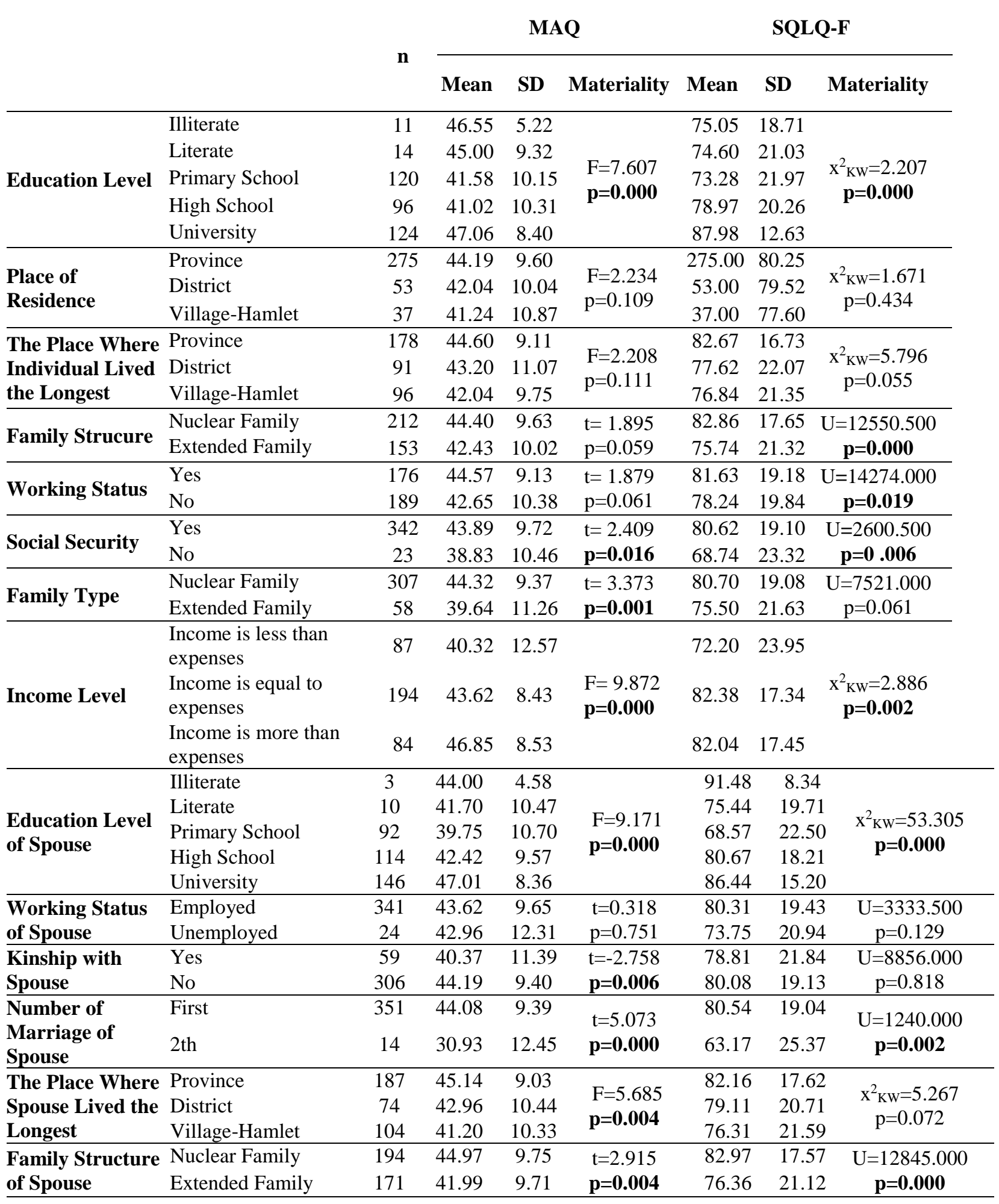

As shown in Table 5, MAQ average score difference depending on the women's place of residence, the place where individual lived the longest, family structure, working status and the working status of spouse wasn't found statistically significant ( $p>0.05)$. Depending on the education level, social security, family type, income level, education level of spouse, kinship with spouse, number of marriages of spouse, the place where spouse lived the longest and family structure of spouse, MAQ average score difference was found statistically significant $(\mathrm{p}<0.05)$. 
While CYK-K average score difference depending on the women's place of residence, the place where individual lived the longest, family structure, working status of spouse, kinship with spouse and the place where spouse lived the longest wasn't found statistically significant ( $\mathrm{p}>0.05)$, CYK-K average score difference depending on the education level, family structure, working status, social security, income level, education level of spouse, number of marriages of spouse and family structure of spouse was found statistically significant $(\mathrm{p}<0.05)$. The average score of the ones who live in a nuclear family, work, have social security, the ones whose spouses have just one marriage, and the ones whose spouses live in a nuclear family is higher (Table 5).

In the advanced analysis done to determine which groups the difference is based on according to the level of education (Dunnet C); the average score of university graduates was found to be higher than that of primary and high school graduates. In the advanced analysis done to determine which groups the difference is based on according to the income level (Dunnet $\mathrm{C}$ ); the scores of the ones whose income is more than expenses were found higher than the ones whose income is equal to expenses or less than expenses.

In the advanced analysis done to determine which groups the difference is based on according to the education level of spouse (LSD); the average score of university graduates was found to be higher than that of primary and high school graduates.

In the advanced analysis done to determine which groups the difference is based on according to the place where spouse lived the longest; the scores of the ones who live in the same city with spouses was found to be higher than the ones who live in village or hamlet.

Table 6. Comparison of the Points Obtained from Marital Adjustment and Sexual Quality of Life QuestionnaireFemale Form According to Marriage and Fertility Characteristics of Married Women (n=365)

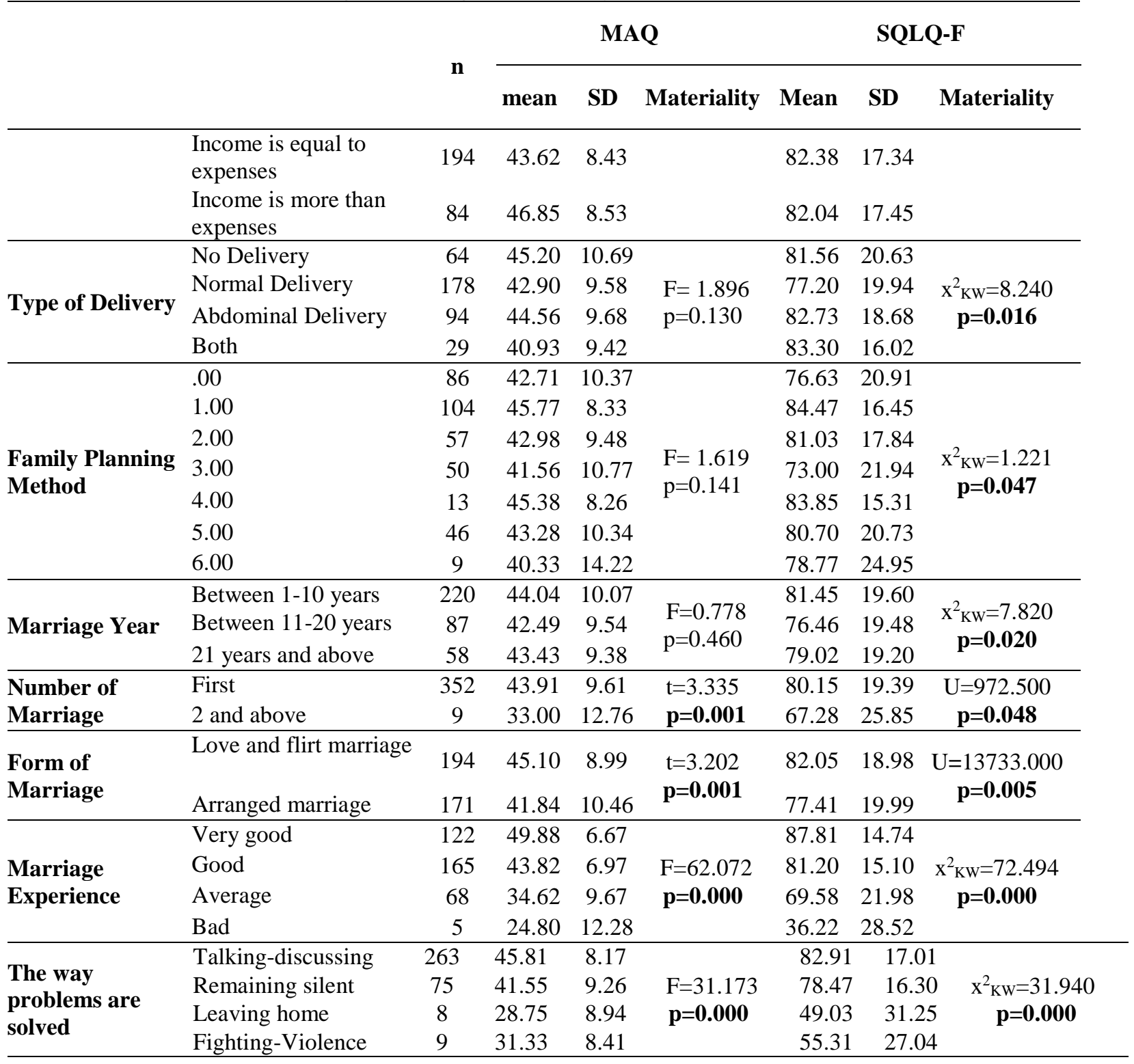




\begin{tabular}{|c|c|c|c|c|c|c|c|c|}
\hline \multirow{3}{*}{ Physical Violence } & Often & 4 & 21.75 & 11.84 & \multirow{3}{*}{$\begin{array}{l}F=48.795 \\
\mathbf{p}=\mathbf{0 . 0 0 0}\end{array}$} & 36.11 & 21.32 & \multirow{3}{*}{$\begin{array}{c}\mathrm{x}^{2}{ }_{\mathrm{KW}}=28.195 \\
\mathbf{p}=\mathbf{0 . 0 0 0}\end{array}$} \\
\hline & Sometimes & 31 & 31.03 & 9.85 & & 63.98 & 25.83 & \\
\hline & Never & 330 & 45.02 & 8.61 & & 81.90 & 17.53 & \\
\hline \multirow{3}{*}{$\begin{array}{l}\text { Emotional } \\
\text { Violence }\end{array}$} & Often & 20 & 31.60 & 12.14 & \multirow{3}{*}{$\begin{array}{l}F=56.351 \\
\mathbf{p}=\mathbf{0 . 0 0 0}\end{array}$} & 58.50 & 27.70 & \multirow{3}{*}{$\begin{aligned} \mathrm{x}^{2}{ }_{\mathrm{KW}} & =38.189 \\
\mathbf{p} & =\mathbf{0 . 0 0 0}\end{aligned}$} \\
\hline & Sometimes & 134 & 39.34 & 8.82 & & 74.96 & 20.90 & \\
\hline & Never & 211 & 47.40 & 8.07 & & 85.02 & 15.23 & \\
\hline \multirow{3}{*}{$\begin{array}{l}\text { Tension } \\
\text { Experience }\end{array}$} & Often & 35 & 28.49 & 10.96 & \multirow{3}{*}{$\begin{array}{l}F=76.650 \\
\mathbf{p}=\mathbf{0 . 0 0 0}\end{array}$} & 54.86 & 29.64 & \multirow{3}{*}{$\begin{array}{c}\mathrm{x}^{2}{ }_{\mathrm{KW}}=37.233 \\
\mathbf{p}=\mathbf{0 . 0 0 0}\end{array}$} \\
\hline & Sometimes & 287 & 44.31 & 8.19 & & 81.65 & 16.22 & \\
\hline & Never & 43 & 50.95 & 5.83 & & 88.37 & 14.10 & \\
\hline \multirow{5}{*}{ Mood } & Love-respect & 310 & 45.91 & 7.72 & \multirow{5}{*}{$\begin{array}{l}F=59.432 \\
\mathbf{p}=\mathbf{0 . 0 0 0}\end{array}$} & 83.02 & 15.99 & \multirow{5}{*}{$\begin{array}{c}\mathrm{X}^{2}{ }_{\mathrm{KW}}=38.710 \\
\mathbf{p}=\mathbf{0 . 0 0 0}\end{array}$} \\
\hline & Hate-tension & 10 & 26.50 & 10.49 & & 44.56 & 28.19 & \\
\hline & $\begin{array}{l}\text { Monotony- } \\
\text { ordinariness }\end{array}$ & 38 & 32.26 & 8.36 & & 70.70 & 22.27 & \\
\hline & Fear-timidity & 7 & 26.00 & 16.01 & & 40.79 & 30.07 & \\
\hline & Extended family & 171 & 41.99 & 9.71 & & 76.36 & 21.12 & \\
\hline
\end{tabular}

As shown in Table 6, MAQ average score difference depending on the women's type of delivery, family planning method and marriage year wasn't found statistically significant ( $>0.05$ ). Depending on the number of marriage, form of marriage, marriage experience, the way problems are solved, physical violence, emotional violence, tension experience, and mood, MAQ average score difference was found statistically significant $(\mathrm{p}<0.05)$. The average score is higher for those experiencing the first marriage and having love and flirt marriage.

In the advanced analysis done to determine which groups the difference is based on according to the marriage experience (Dunnet C); the average score of the ones whose marriage experience is very good was found to be higher than that of average and bad ones.

In the advanced analysis done to determine which groups the difference is based on according to the way of problems are solved in a marriage (LSD); the score of the ones who talk and discuss was found to be higher than the ones remaining silent, leaving home, fighting and applying violence and reflecting on families and the acquaintances.

In the advanced analysis done to determine which groups the difference is based on according to the physical violence (LSD); the average score of the ones answering "often" was found to be lower than the ones answering "never" or "sometimes".

In the advanced analysis done to determine which groups the difference is based on according to the emotional violence (Dunnet C); the average score of the ones answering "often" was found to be lower than the ones answering "never" or "sometimes".

In the advanced analysis done to determine which groups the difference is based on according to the tension experience (Dunnet C); the average score of the ones answering "often" was found to be lower than the ones answering "never" or "sometimes".

In the advanced analysis done to determine which groups the difference is based on according to the mood (Dunnet C); the score of the ones answering love and respect was found to be higher than the ones answering hate-tension and monotony.

In Table 6, SQLQ-F average score difference depending on the women's type of delivery, family planning method, marriage year, number of marriage, form of marriage, marriage experience, the way problems are solved, physical violence, emotional violence, tension experience, and mood was found statistically significant $(\mathrm{p}<0.05)$. The average score of the ones having the first marriage is higher.

In the advanced analysis done to determine which groups the difference is based on according to the type of delivery (U); the score of the ones without delivery or having abdominal delivery was found higher than the ones having normal delivery.

In the advanced analysis done to determine which groups the difference is based on according to the family planning method (U); the difference was determined between 0-1 (0-kondom). The scores of those who use condoms are higher.

In the advanced analysis done to determine which groups the difference is based on according to the marriage year (U); the score of the ones having been married for 1-ten years was found to be higher than the ones having been married for 1120 years. 
In the advanced analysis done to determine which groups the difference is based on according to the marriage experience (U); the score of the ones whose marriage experience is "very good" was found to be higher than the ones whose marriage experience is "good", "average" or "bad".

In the advanced analysis done to determine which groups the difference is based on according to the way of solving problems (U); the score of the ones talking and discussing was found to be higher than the ones remaning silent, leaving home, fighting and applying violence and reflecting on family and acquaintances.

In the advanced analysis done to determine which groups the difference is based on according to the physical violence (U); the score of the ones answering "never" was found to be higher than the ones answering "often" and "sometimes."

In the advanced analysis done to determine which groups the difference is based on according to the emotional violence (U); the score of the ones answering "never" was found to be higher than the ones answering "often" and "sometimes."

In the advanced analysis done to determine which groups the difference is based on according to the tension experience (U); the score of the ones answering "never" was found to be higher than the ones answering "often" and "sometimes."

In the advanced analysis done to determine which groups the difference is based on according to the mood; the score of the ones answering love and respect was found to be higher than the ones answering hate and tension, monotony, fear and timidity.

Table 7. Analysis of the relationship between the age, number of children, age of marriage and age of spouse and SQLQ-F and MAQ

\begin{tabular}{llcc}
\hline & & MAQ & SQLQ-F \\
\hline \multirow{2}{*}{ Age } & $\mathrm{R}$ & -0.002 & -0.118 \\
& $\mathrm{P}$ & 0.971 & $\mathbf{0 . 0 2 4}$ \\
\hline \multirow{2}{*}{ Number of Children } & $\mathrm{R}$ & -0.067 & -0.139 \\
& $\mathrm{P}$ & 0.200 & $\mathbf{0 . 0 0 8}$ \\
\hline \multirow{2}{*}{ Age of Marriage } & $\mathrm{R}$ & 0.219 & 0.193 \\
& $\mathrm{P}$ & $\mathbf{0 . 0 0 0}$ & $\mathbf{0 . 0 0 0}$ \\
\hline \multirow{2}{*}{ Age of Spouse } & $\mathrm{R}$ & -0.091 & -0.189 \\
& $\mathrm{P}$ & 0.083 & $\mathbf{0 . 0 0 0}$ \\
\hline
\end{tabular}

In Table 7, there is no statistically significant relationship between women's age, number of children and spouse age and MAQ ( $p>0.05)$. There is a low level positive correlation between age of marriage and MAQ ( $<<0.05)$. As the age of marriage increases, the MAQ score increases. There is a statistically significant negative correlation between age, number of children and spouse age, and SQLQ-F score $(\mathrm{p}<0.05)$. As the age, number of children and the age of the spouse increase, the SQLQ-F score decreases. There is a low positive correlation between age of marriage and SQLQ-F score (p $<0.05)$. As the age of marriage increases, the SQLQ-F score increases.

Table 8. Analysis of the relationship between SQLQ-F and MAQ

\begin{tabular}{llc}
\hline & & SQLQ-F \\
\hline \multirow{2}{*}{ MAQ } & $\mathrm{r}$ & 0.514 \\
& $\mathrm{p}$ & $\mathbf{0 . 0 0 0}$ \\
\hline
\end{tabular}

As seen in Table 8, there İS a moderate and positive significant relationship between MAQ and SQLQ-F scores ( $\mathrm{p}<0.05)$. The higher the MAQ is, the higher the SQLQ-F score.

\section{DISCUSSION}

In the study, depending on the education level, social security, family type, income level, education level of spouse, kinship with spouse, number of marriages of spouse, the place where spouse lived the longest and family structure of spouse, MAQ average score difference was found statistically significant ( $p<0.05$ ). The average score of the ones having social security, living in a nuclear family, not having kinship with the spouse, being spouse's first marriage, and the ones whose spouse 
living in a nuclear family is higher. SQLQ-F average score difference depending on the women's education level, family structure, working status, social security, income level, education level of spouse, number of marriage of spouse, and family structure of spouse was found statistically significant $(\mathrm{p}<0.05)$. The score of the ones living in a nuclear family, working and having social security, having the first marriage, and being spouse's first marriage was found higher (Table 5).

In the study, it was found out that the university graduates have higher marital adjustment. Although there are studies showing that as the education level increases [15] couple adjustment and marital adjustment increase too [16], in contrast to these findings, there are studies available showing that individuals with high education levels have low marriage satisfaction[12] and have more marriage conflicts[15]. According to the results of the study, it can be said that the high education level of women brings along the work of women and the right to have a say in marriage, and as a result of which the marital adjustment is positively affected. However, the men in our society are brought up patriarchally and it brings along conflicts.

In the study, the marital adjustment of the families living in the nuclear family was found to be higher. According to the study done by Yalçın, although the type of family does not affect the marital adjustment of women[7], it has been determined that the marital adjustment of individuals with a nuclear family structure is higher [16]. In the literature, this situation is said to be caused by the conflict with the family elders in the extended families that originate from the traditional understanding in our society [16]. Although there are differences in the findings of the study, in the study done by Yalçın, it is thought that the fact that the number of people living in the extended families is very limited when compared to the number of people living in a nuclear family affects the finding.

In our study, the fact that the marital adjustment of the ones living in the nuclear family is high also affects sexuality and caused high quality of sexual life. It is thought that people living in the nuclear family is be more likely to decide on marriage issues together and their privacy is more likely to be protected than the ones living in extended families. And as a result of this, it is thought that family and community pressure is less for this group and this can increase sequal quality of life.

In the study, it was determined that the marital adjustment and sexual quality of life of women with good economic status and social security were high. In many studies done, it was found that the marital adjustment of individuals with good economic status and social security was high[15,16,17]. This shows that couples who are experiencing economic problems more often experience conflict and fail to cope with the problems. This is an indicator of the variability of marital adjustment according to the changing income level of the family. It is thought that the quality of sexual life will increase in families where marriages are compatible and economic conflicts are low.

In our research findings, the employment status of women does not affect marital adjustment, but it affects the quality of sexual life. In his study, Öztürk emphasized once again that as in the case of individuals having high socioeconomic level, in cases where the financial dependence decreases, emotional attachment and interrelation are very important for the increase in marital adjustment and the marriage satisfaction[6]. It can be said that this will increase the marital adjustment and the quality of sexual life. In the study done in Konya, a significant relationship was found between the profession of women and marital adjustment [16] to our findings, while working status does not affect the marital adjustment, it affects the quality of sexual life. It is thought that the findings in the studies may be different because of the differences in the regions where the studies are conducted and the cultural characteristics of the place. In addition, women's income status rather than working status is more important in marriage and we can relate this to working status of men in our culture and the role of man in bringing home the bacon. We can say that women's participation in sexuality may affect the quality of sexual life with the idea that independence stemming from women's working status and participation in decisions may lead to the emergence of decision-making in sexuality.

In the study, it was found that there was a significant relationship between sexual quality of life and marital adjustment and the education level of the spouse and the marital adjustment and sexual quality of life of the spouses having a university degree were found to be higher. In the studies conducted, it was found that the educational status of the spouses affected the marital adjustment, and that the marital adjustment of the spouses was higher as the education status of the spouses increased [16,17]. The high level of spouses' education level means that the spouse is away from the family during education period, s/he flirts with the opposite sex and there are more mutual interactions and s/he moves away from the culture and all these can be claimed to lead to more independent decision-making in marriages and it can be said that this situation contributes positively to marriage and sexuality.

In the study, MAQ average score difference depending on the women's number of marriage, form of marriage, marriage experience, the way the problems are solvd, physical violence, emotional violence, tension experience and mood was found to be statistically significant $(\mathrm{p}<0.05)$. The average score of the ones having the first marriage by love and flirting was found higher. SQLQ-F average score difference depending on the women's type of delivery, family planning method, marriage year, year of marriage, number of marriage, form of marriage, marriage experience, the way the problems are 
solved, physical violence, emotional violence, tension experience and mood was found to be statistically significant $(\mathrm{p}<0.05)$. The average score of the ones having the first marriage was found higher (Table 6).

Marriage harmony is defined as a marriage of couples who can interact with each other, agree on issues related to marriage and family and solve problems in a positive ways. Effective problem-solving ability in marital problems contributes to marital satisfaction [18]. In a study done, it was found that the marital adjustment of couples who communicate and share their thoughts and feelings was better[16]. As it can be understood from these results, there is an important connection between communication and marital adjustment. This connection is likely to affect sex life and it is a result that we expect an increase in the quality of sexual life of women with good communication in marriage.

Mood (love, respect, hate, tension etc.) affects the sexual life of people and their harmony in marriage. In the study, marital adjustment and sexual quality of life of the women who have love-respect towards their spouses were found to be higher. In parallel with our findings, there are studies showing that the couples' satisfaction with marriage [19] and marital adjustment[3] increase as the interpersonal positive relationship level increases. In another study, sexual life quality of women with intense feelings of her husband is also found to be high[7]. The findings of the research are similar. It is thought that love, respect and love increase the harmony in the marriage and in parallel with this, it affects sexuality and increases sexual quality of life.

In the study, it was found that the marital adjustment and sexual quality of life of the women who were frequently exposed to emotional violence was low. The studies done supports our findings and they show that the marital adjustment and satisfaction of women exposed to violence [17] is low [20]. According to these results, we can say that the violence against women affects marriage and sexuality negatively.

Marriages in which men and women accept living together voluntarily and promise each other for love and loyalty provide a basis for increased emotions and intense gratifications [21]. In our study, it was determined that the marital adjustment and sexual quality of life of the couples married by love or flirting were high. In the studies conducted, it was found that the marriage form of women affects the marital adjustment scores and that the marital adjustment scores of the women who voluntarily married were higher and the difference was statistically significant $(\mathrm{p} \leq 0.05)[16,17]$. According to these results, when individuals marry by love and on their own will, marital adjustment and relations with their spouses will be better. In the literature, it is seen that in the social level, sexuality is related to the values and legal rules of the society, the ways of people's life, the roles community give to different genres, sexuality idea, their choice of spouses and their choice of marriage [22]. According to our results, there is a positive relationship between marital adjustment and sexual quality of life and peer choice. The literature supports our research.

In our study, the sexual quality of life of non-delivery and cesarean delivery was found to be higher than in the normal delivery group. According to the results of a study, there were significant differences between the vaginal and interventional birth groups according to the female sexual function questionnaire (SFQ28). In the same study, there was a significant difference between the non-laceration group and the episiotomy groups in the perceptual dimension. According to another finding of the study, significant differences were observed in the partner area of SFQ28 between vaginal and operative delivery groups [23]. In Kasap et al.'s study, it is shown that vaginal delivery does not adversely affect postnatal sexual functions. However, these results have been reported to be confirmed by clinical studies with prospective and larger patient groups[24]. While some studies have shown that there is a relationship between sexual function and type of delivery, episiotomy and laceration, the other studies don't. In conclusion, it is recommended that more research is necessary to determine the relationship between the mother's sexual health and the postpartum sexual function, and routine episiotomy should be avoided during childbirth in order to improve maternal sexual function after childbirth.

In the study, while no significant relationship between marital adjustment and marriage year was found, a significant relationship was found between sexual quality of life and it was found that the group that created difference was between 1 and 10 years. In the study done by Şener and Terzioğlu, it was found that there was no significant relationship between marital adjustment $(F=659 ; p=577)$ and marriage year [25]. Şener's study and our study are in parallel. In our study, there was a significant relationship between sexual quality of life and marriage year. In Y1lmaz and Avc1's study, sexual quality of life of the ones having the spouse's first marriage is higher[17]. In another study, it was found that there was a statistically significant relationship between women's marriages year and their evaluation of marriage and sexual life and their feelings towards their spouses [7].

In the literature, it is stated that the importance of sexuality for marital satisfaction is not understood without passing a few years in marriage and lack of sexual desire in marriage is about the duration of marriage[4]. Gülsün marital adjustment According to the research, the quality of sexual life was higher in the first years of marriage. It is thought that sexual life can be affected with the onset of menopause and chronic diseases in the direction of female physiology during the passing years. 
In our study, it was found that sexual quality of life and marital adjustment were affected by physical and emotional violence. It was found out that the scores of the ones answering "often" for physical violence is less than the ones answering "never" or "sometimes". It is reported in the literature that consciously or unconscious conflicts play an important role in the development of sexual dysfunction and in a relationship that is not complemented by emotional convergence and thought sharing, the ability of sexual function and satisfaction may be reduced[4].

In Y1lmaz and Avcı's study, when the effect of women's exposure to violence on marital adjustment is evaluated, it was found out that women's exposure to violence affect their marital adjustment score; that the scores of women who are not exposed to violence is higher than the women who are exposed to violence and that the difference was found to be statistically significant[17]. In another study, according to the quality of sexual life questionnaire applied to participants, sexual quality of life was found significantly higher in those who were not exposed to domestic violence compared to those exposed to domestic violence [20]. Violence is expected to affect sexuality that is integrated into marriage in a situation where it affects marital adjustment. According to these results, the rate of women experiencing violence is not low; ee can say that violence can be experienced in families of all levels and that the situation negatively affects marriage and sexuality.

In our research findings, marital adjustment and sexual quality of life were found to be low in the marriages in which spouses experience tension. When the literature is evaluated in general, it is understood that marriage satisfaction of women accusing their husbands for marriage relations is less, that the ones experiencing disharmony in marriage evaluate their spouses' behavior as deliberate and selfish and accuse their spouses excessively when they show negative behavior. According to the literature, in a study using the Marriage Life Scale shows that conflict and tension situations lead insufficient satisfaction from marriage [4]. The conflicts associated with the spouse affect marriage and affect sexuality. Conscious or unconscious conflicts related to the spouse play an important role in the formation of sexual dysfunction. In a relationship that is not complemented by emotional convergence and sharing of thought, the adequacy and satisfaction of the sexual function may be reduced[4]. Marriage harmony and sexuality is expected to be affected in a marriage in which tension is experienced.

There is a significant difference between the family planning method and sexual life quality, and the scores of the condom users are higher. In a study, it was determined that the sexual functions of women who prefer modern family planning methods are better than those using traditional family planning methods, and that the sexual response is strong, easy and satisfying. In the same study, it was stated that while performing the family planning services, it may be useful for nurses to evaluate their applicants' sexual health and self-esteem in order to choose the most appropriate and effective method for them[26]. The use of condoms means that the man participates in the family planning method and the woman accepts it and it means that they can decide together. This may lead to a more satisfying sexuality in two groups. The results show that couples choose the most suitable modern method for themselves and increase the effectiveness of the AP method.

According to our findings, while there is no relationship between age, number of children and marital adjustment, as age, number of children and the age of the spouse increase, the quality of sexual life decreases. Sexual life quality increases as marriage year increases (Table 7).

According to the literature information, one of the important factors affecting sexual life in marriage relationship is children. In addition to being desired and indispensable part, child has also been reported as a barrier between spouses and the presence of children reduces the frequency of sexual intercourse. In the same literature, Call and Schwartz reported that the presence of young children reduces the frequency of sexual intercourse in a study[4]. It is thought that sexuality can be affected as a result of children's illnesses, nighttime disturbances and sleep disturbances, which can lead to tiredness and restlessness in spouses.

According to our results, it was found that the number of children did not affect the marital adjustment. According to Yalçın's study, it was concluded that there is no significant difference between marital adjustment and number of children of women [7]. In the study performed by Pinar Çağ et al., the duration of marriage, age difference between spouses and number of children were found to affect marital satisfaction[12]. In another study, no significant relationship was found between the duration of marriage, age of marriage and age of marriage of spouse and MAQ[16]. are differences between the studies about children. In literature, in addition to being a desired and indispensable part, child is also stated as a barrier between spouses[4].It can be said that this difference can be the reason for the difference between the studies.

In this study done to investigate the effect of marital adjustment on sexual quality of life, it was found that as the score of Marital Adjustment Questionnaire (MAQ) increases, the score of Sexual Quality of Life Questionnaire (SQLQ) increases and as the martal adjustment decreases, satisfaction from sexual intercourse decreases, too (Table 8).

The spouse relationship is also characterized by sexuality, as well as social, economic and cultural interactions in the marriage institution. Sexuality is one of the important factors that can affect the harmony between spouses and all areas in marriage[4]. In a study investigating the relationship between sexual function and happiness in marriage, it was determined that factors such as sexual satisfaction, the way the couples perceive it and the frequency of sexual intercourse affect happiness positively in marriage and the increase in negative emotional reactions, the decrease in the frequency of sexual 
intercourse and the satisfaction of happiness negatively affect the marriage (Morokoff ve Gilliland). In another study, it was found that the marital satisfaction increased as the sex life satisfaction increased, and marriage satisfaction was high in individuals with perceived high spousal support and sexual satisfaction [12]. In the study done by Öztürk and Arkar, it was found that as the marital adjustment decreased, sexual satisfaction decreased [6]. The studies have revealed that individuals who share sexual problems with their spouses have higher marital adjustment[16]. that couples without sexual problems have higher couple adjustment [18].; that couples with good quality of sexual life have higher marriage harmony [20]. In Collins and Coltrane's study, it was fount out that marital adjustment is determined by marriage happiness as well as criteria such as sexual satisfaction [8,27]. have defined marital adjustment as spouses' having positive feelings and thoughts about each other, good communication ability, ability to solve conflicts, and doing activities together by taking pleasure. The studies done revelaed that the satisfaction of spouses' sexual relations significantly affects marital adjustment [9], sexual dysfunctions cause unhappiness in marriage and sexual satisfaction, the way couples perceive it and the frequency of sexual intercourse have been found to be directly proportional to happiness in marriage[11].

The literature indicates that sexuality takes place in all stages of marriage, which is one of the basic elements of society. The problems occurring in other areas of marriage may have effects on sexuality, and problems in sexual life may have effects in other ares of marriage relationship. Both marital and sexual functions can be affected in different degrees and shapes by biological, psychological and even sociocultural factors. In our country, the reflections of marriage on sexuality and sexuality on marriage appear as a research area that should be emphasized[4].Studies and literature information support our study and it is not possible to think about sex in marriage separately from the general communication of the couple. Therefore, it is expected that non-communication or conflicts between spouses will also affect sexual function.

\section{CONCLUSION AND SUGGESTIONS}

As a result; In this study, which was conducted to investigate the effect of marital adjustment on sexual quality of life, it was found that as the marital adjustment of women increased, the quality of sexual life increased and as the marital adjustment of women decreased, the satisfaction obtained from sexual intercourse decreased. It has been determined that some variables such as education level, social security, family type, income level, education level of spouse, kinship with spouse, marriage number of spouse, family structure of spouse affect women's marital adjustment and sex life quality. In addition, it was determined that the marital characteristics of women such as form of marriage, marriage experience, the way probles are solved, physical violence, emotional violence, tension experience, and mood affect the marital adjustment and sexual quality of life. Studies on the subject are insufficient in our country. That's why it is suggested to do more comprehensive studies; nurses should provide pre-marital and marriage counseling to ensure family integrity and to increasemarital harmony and sexual quality of life and family consultations should developing strategies to raise awareness of sexual issues for families and educate families to improve their communication skills.

\section{REFERENCES}

1. Budak S. Psikoloji Sözlüğü, 3. Bask1. Ankara, Bilim ve Sanat Yayınları, 2005:155

2. T.C. Başbakanlık Aile ve Sosyal Araştırmalar Genel Müdürlüğü. Aile Rehberi. ISBN: 975-19-3778-7 Ankara, 2005

3. Kışlak Tutarel Ş, Çabukça F. Empati ve Demografik Değişkenlerin Evlilik Uyumu ile İlişkisi . Aile ve Toplum Eğitim Kültür ve Araştırma Dergisi, 2002 , Cilt : 2 Sayı : 6

4. Gülsün ., Ak M., Bozkurt A., Psikiyatrik Açıdan Evlilik ve Cinsellik Marriage and Sexuality From a Psychiatric Point of View , Psikiyatride Güncel Yaklaşımlar-Current Approaches In Psychıatry 2009; 1(1):68-79

5. Cinsel Sağlık ve Üreme Sağlığı Alanında Ulusal ve Yerel Medya Yoluyla Savunuculuk Projesi, bilgilendirme dosyası 1: cinsel yaşam ve sorunları, Cinsel Eğitim Tedavi ve Araştırma Derneği, www.cetad.org.tr/CetadData/Book/5/2692011151611-bilgilendirme_dosyasi_1. Erişim tarihi 13.01.2016, saat 11:00, sayfa $7-9$.

6. Şafak Öztürk C, Arkar H. Evli Çiftlerde Evlilik Uyumu ve Cinsel Doyum Arasındaki İlişkiler. Literatür Sempozyum, $1(3), 16-24$.

7. Yalçın H., Evlilik Uyumu İle Sosyodemografik Özellikler Arasındaki İlişki, Eğitim ve Öğretim Araştırmaları Dergisi Journal of Research in Education and Teaching Şubat 2014 Cilt:3 Sayı:1 Makale No: 24 ISSN: 2146-9199

8. Collins, R.S., Coltrone, S. (1991). Sociology of marriage and the family: gender, love and property, 3. Bask1, Chicago.

9. Huston, L., Vangelesti, A.L. (1991). Socioemotional behavior and satisfaction in marital relationships: A longitudinal study. Journal of Personality and Social Psychology, s:721-733. 
10. Rust J, Golombok S, Collier J. Marital problems and sexual dysfunction: How are they related? Br J Psychiatry 1988; 152:629-631.

11. Morokoff J, Gillilland R. Stress, sexual functioning, and marital satisfaction. J Sex Res 1993; 30:43-53.

12. Çağ P., Yildirim İ., Evlilik Doyumunu Yordayan İlişkisel ve Kişisel Değişkenler Relational and Personal Predictors of Marital Satisfaction Türk Psikolojik Danışma ve Rehberlik Dergisi 2013, 4 (39), 13-23

13. Kışlak-Tutarel, Ş. (1999). Evlilikte uyum ölçeğinin (EUÖ) güvenirlik ve geçerlik çalışması. 3P Psikiyatri Psikoloji Psikofarmakoloji Dergisi, 7(1), 54-56

14. Tuğut N., Gölbaşı Z., Cinsel Yaşam Kalitesi Ölçeği - Kadın Türkçe versiyonunun geçerlik ve güvenirlik çalışması, Cumhuriyet Tip Dergisi 2010; 32: 172-180

15. Şendil G, Korkut Y. Evli Çiftlerdeki Çift Uyumu Ve Evlilik Çatışmasının Demografik Özellikler Açısından İncelenmesi. İstanbul Üniversitesi Psikoloji Çalışmaları Dergisi,2008, Volume: 28,Number: 1

16. Şule Karadağ, Evlilik Uyumu İlişkisinde Aile İçi İletişimin Rolü: Konya Örneği, Selçuk Üniversitesi Sosyal Bilimler Enstitüsü Halkla İlişkiler Ve Tanıtım Ana Bilim Dalı, Halkla İlişkiler Bilim Dalı Doktora Tezi Konya-2015

17. Yılmaz A, Aydın Avcı İ. 15-49 Yaş Grubu Evli Kadınların Bazı Toplumsal Cinsiyet Özellikleri İle Evlilik Uyumları Arasındaki İlişki. Gümüşhane Üniversitesi Sağlık Bilimleri Dergisi / Gümüşhane University Journal of Health Sciences: $2015 ; 4(2)$

18. Erbek E., Beştepe E., Akar H., Alpkan L., Eradamlar N., Cinsellik ve Çift Uyumu Arasındaki İlişki: Üç Grup Evli Ciftte Karşılaştırmalı Bir Çalışma, Düşünen Adam; 2005, 18(2): 72-81.

19. Kasapoğlu F., Kultu M., Durmuş M., Evli Bireylerde Kişilerarası İlişki Tarzı ile Evlilik Doyumu Arasındaki İlişki: Evlilikte Özyeterlik Algısının Aracı Rolü, Nesne Psikoloji Dergisi (NPD), 2017, Cilt 5, Sayı 11, Volume 5, Issue 11

20. Tav AŞ., , Gültekin BK., , SarIöz Arpaccıŏlu B., Aile içi fiziksel şiddete maruz kalmış evli kadınlarda klinik özellikler, çiftlerarası uyum ve cinsel yaşam kalitesi, Clinical characteristics, adjustment between the couples and the quality of sexual life of married women who are exposed to physical domestic violence, Klinik Psikiyatri, 2018;21:254-260

21- Bakırcıŏlu R, Ansiklopedik psikoloji sözlüğ̈̈. Ankara, Anı yayıncılık.2006

22. Yılmaz Esencan T., Kızılkaya Beji N., Günümüze değin cinsellik konusunda yapılan çalışmaların irdelenmesi, Kadın Cinsel sağlığı, https://www.researchgate.net/, Erișim Tarihi: 13.11.2018 saat: 16:35

23. Cinsel sağlık ile doğum biçimi arasındaki ilişki, Çeviri Yrd. Doç. Dr. Can Benlioğlu, Prof. Dr. Sefa Resim, Adıyaman Üniversitesi Tıp Fakültesi, Üroloji AD Kahramanmaraş Sütçü İmam Üniversitesi Tıp Fakültesi, Üroloji ADSong M., Ishii H., Toda M. Sex Med 2014; 2: 153-8

24. Kasap E. , Aksu EE.,, Şahin N., Güçlü S., Gür EB., Doğum şeklinin seksüel fonksiyon üzerine etkisi var mıdır?, Tepecik Eğit. ve Araşt. Hast. Dergisi 2016; 26(3):201-206 doi:10.5222/terh.2016.201

25. Şener, A. ve Terzioğlu, G. (2008). Bazı sosyo-ekonomik ve demografi k değişkenler ile iletişimin eşler arası uyuma etkisinin araştırılması. Aile ve Toplum Dergisi, 4(13), 7-20.

26. Egelığlu Cetışlın N., Top ED., Arkang G., Kaba F., Ertop F., Evli Kadınların Kullandıkları Aile Planlaması Yönteminin Cinsel Yaşam ve Benlik Saygısına Etkisi (The Effects That Family Planning Methods Have On Married Women's Sexual Health And Selfesteem), Hemşirelikte Eğitim Ve Araştırma Dergisi, 2016;13 (2): 101-106[

27. Halford, WK., Kelly, A, Markman, H. L. (1997). The concept of a healthy marriage. Clinical Handbook of Marriage and Couple Intervention. 